\title{
Potential Zones of Peruvanthanam and Valiyathodu Sub-Watersheds of Manimala River Basin
}

\author{
${ }^{1}$ Vadakkepurakkal Rekha, ${ }^{2}$ Aikara Varkey George and ${ }^{3}$ Rita Mendez \\ ${ }^{1}$ School of Environmental Sciences, \\ Faculty of Environmental Sciences, Mahatma Gandhi University, Kottayam, Kerala, India \\ ${ }^{2}$ Department of Environmental Science, Faculty of Environment, \\ Energy and Earth Sciences, Central University of Kerala, Kasargode, Kerala, India \\ ${ }^{3}$ Department of Chemistry, Faculty of Chemistry, Government Engineering College, Thrissur, Kerala, India
}

Received 2012-10-23, Revised 2013-03-26; Accepted 2013-03-28

\begin{abstract}
Groundwater is a dynamic and replenishable natural resource. But in hard rock terrains, its availability is of limited extent. In sub-watershed studies, remote sensing and GIS techniques have the advantages of spatial, spectral and temporal data, covering large and inaccessible areas within a short span of time. Thus this technique has become a very handy tool in assessing and monitoring groundwater resources. Multi Criteria Evaluation Technique (MCE) by integration of the thematic maps such as Geomorphology, Geology, Land use/Land cover and Slope prepared from conventional and remote sensing techniques using GIS yield more and near accurate result. The groundwater potential zones are classified in to five zones viz, 'excellent to very good', 'very good to good', 'good to moderate', 'moderate to poor' and 'poor to very poor'. Critical analysis and comparison of ground water potential zones of both sub-watersheds reveals that, $26.10 \mathrm{~km}^{2}$ $(47.58 \%)$ area of Valiyathodu sub-watershed fall under 'excellent to very good' category where as in Peruvanthanam sub-watershed it is $7.69 \mathrm{~km}^{2}(13.64 \%)$. In Peruvanthanam sub-watershed, "very good to good' category covers $14.87 \mathrm{~km}^{2}(26.35 \%)$, 'good to moderate' covers $17.65 \mathrm{~km}^{2}(31.28 \%)$, 'moderate to poor' covers $11.62 \mathrm{~km}^{2}(20.59 \%)$ and 'poor to very poor' covers $4.59 \mathrm{~km}^{2}(8.14 \%)$. Where as in Valiyathodu sub-watershed, 'very good to good' category covers an area of $18.55 \mathrm{~km}^{2}(33.82 \%)$, 'good to moderate' covers $6.65 \mathrm{~km}^{2}(12.12 \%)$ and 'moderate to poor' covers $2.43 \mathrm{~km}^{2}(4.43 \%)$ and 'poor to very poor' covers $1.12 \mathrm{~km}^{2}(2.05 \%)$. Hence it is explicit that, in general groundwater potential is better in Valiyathodu sub-watershed compared to Peruvanthanam sub-watershed.
\end{abstract}

Keywords: Groundwater, Potential Zones, Peruvanthanam Sub-Watershed, Valiyathodu Sub-Watershed, Manimala River Basin

\section{INTRODUCTION}

Groundwater is one of the most valuable natural resources, which supports human life, economic development and ecological diversity. Over exploitation and unabated pollution of this vital resource is threatening our ecosystems and even the life of future generations (Ravishankar and Mohan, 2006).
Exploitation and utilization of groundwater requires proper understanding of its origin, occurrence and movement, which are directly or indirectly controlled by terrain characteristics (Khan and Moharana, 2002). Groundwater occurrence in hard rock terrains are essentially confined to fractured and weathered horizons. Remote Sensing and Geographic Information System (GIS) is one of the leading tools in

Corresponding Author: Vadakkepurakkal Rekha, School of Environmental Sciences, Faculty of Environmental Sciences, Gandhi University, Kottayam, Kerala, India 
hydrogeological science for assessing and monitoring groundwater (Mayilvaganan et al., 2011). The interpretation of satellite data in conjunction with sufficient real ground information makes it possible to identify and outline various ground features such as geological structures, geomorphic features and their hydraulic characters which may serve as direct or indirect indicators of the presence of groundwater (Das et al., 1997; Rao et al., 2000; Ravindran and Jeyaram, 1997; Devi et al., 2001; Gopinath and Saralathan, 2004). Satellite data provides quick and useful baseline information on parameters like geology, geomorphology, land use/land cover, lineaments. which controls the occurrence and movement of groundwater (Saraf and Choudhuray, 1998). With the capabilities of the remote sensing data and GIS techniques, numerous databases can be integrated to produce conceptual model for delineation and evaluation of groundwater potential zones of an area (Krishnamurthy and Srinivas, 1995; Srivasthava and Bhattacharya, 2000; Taylor and Howard, 2000; Sarkar et al., 2001; Prasad et al., 2008). Present investigation was carried out to delineate the areas suitable for groundwater exploration in both Peruvanthanam and Valiyathodu sub-watershed using remote sensing and GIS techniques by the preparation and analysis of various thematic layers. The information, depicted in the form of prospect maps would provide first hand information about areas most suitable for search of groundwater and also the type of well, depth to local authorities and planners.

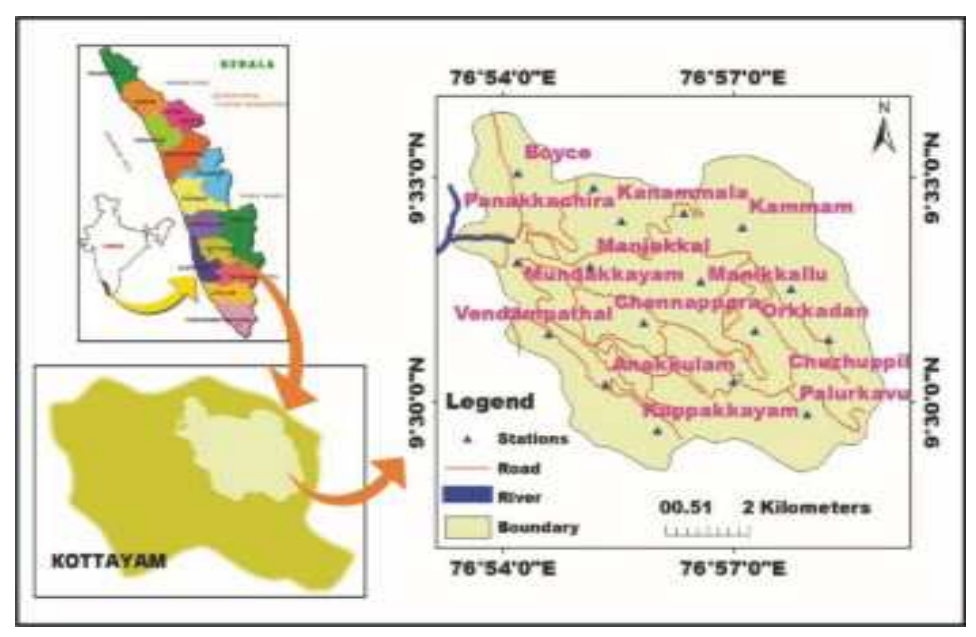

Fig. 1. Location map of Peruvanthanam sub-watershed

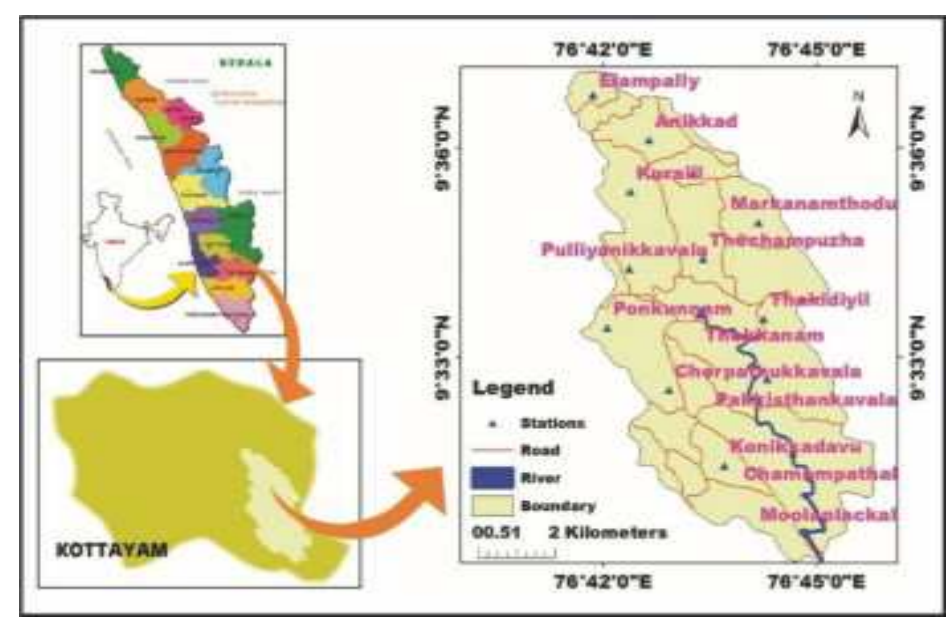

Fig. 2. Location map of Valiyathodu sub-watershed 


\subsection{Study Area}

The area selected for the present investigation i.e., Peruvanthanam and Valiyathodu sub-watersheds belongs to a typical highland and midland subwatersheds of the Manimala river basin. Peruvanthanam sub-watershed (Fig. 1) covers an area of $56.42 \mathrm{~km}^{2}$ and lies between $9^{0} 29^{\prime} 00^{\prime \prime}$ to $9^{0} 34^{\prime} 00^{\prime \prime} \mathrm{N}$ latitude and $76^{0} 53^{\prime} 00^{\prime \prime}$ to $76^{0} 59^{\prime} 00^{\prime \prime}$ E longitude. The Valiyathodu sub-watershed (Fig. 2) lies between $9^{0} 30^{\prime} 00^{\prime \prime}$ to $9^{0} 37^{\prime} 00{ }^{\prime}$ N latitude and $76^{\circ} 411^{\prime} 00^{\prime \prime}$ to $76^{\circ} 46^{\prime} 00^{\prime \prime} \mathrm{E}$ longitude and covers an area of $54.85 \mathrm{~km}^{2}$.

\section{MATERIALS AND METHODS}

Present study involves generation of various thematic maps such as geomorphology, land use/land cover, slope, geology and its analysis, for the identification of groundwater potential zones of both sub-watersheds. Multi Criteria Evaluation technique (MCE) was applied for assigning weightages and scores to assess various themes and features. Instead of taking only one character or parameter in to consideration to identify groundwater potential zones, integrated thematic maps were prepared. The themes generated and the data sources are shown in the Table 1.

\subsection{Geomorphology}

Peruvanthanam sub-watershed is characterized by denudational structural hill, denudational slope, residual hill, residual mound, escarpment, valley fill and water body (Fig. 3). Valiyathodu sub-watershed by linear ridge (Lower plateau), lower plateau (Lateritic)-dissected, residual hill, residual mound, valley fill and water body (Fig. 4). The areas covered by each geomorphic unit of both sub-watersheds are represenred in Fig. 5 and 6.

\subsection{Land Use/Land Cover}

Peruvanthanam sub-watershed is characterized by rubber, tea, teak, mixed crop and cardamom plantations. Evergreen forest, land with scrub, barren rock, built up area and water bodies were also identified (Fig. 7). Valiyathodu is characterized by rubber, mixed crop, land with scrub, built up area and water bodies (Fig. 8). The areas covered by each land use/land cover unit of both the sub-watersheds were represented in Fig. 9 and 10.

\subsection{Slope}

The thematic map of slope for both sub-watersheds, were derived from Digital Elevation Modelling (DEM) using '3D analyst'an extension tool of Arc GIS.9.2.
Table 1. Prepared themes and it's sources

\begin{tabular}{ll}
\hline Themes & Sources \\
\hline Geomorphology & IRS P6 LISS III image; \\
& SOI toposheets $(58 \mathrm{c} / 10,58 \mathrm{c} / 14$ and \\
& 58c/15 of scale 1:50,000); field visit \\
Land use/ & IRS P6 LISS III \\
Land cover & image; field visit \\
Slope & Contours derived from SOI toposheets \\
& Geological map prepared by \\
Geology & GSI (1978); field visit \\
\hline
\end{tabular}

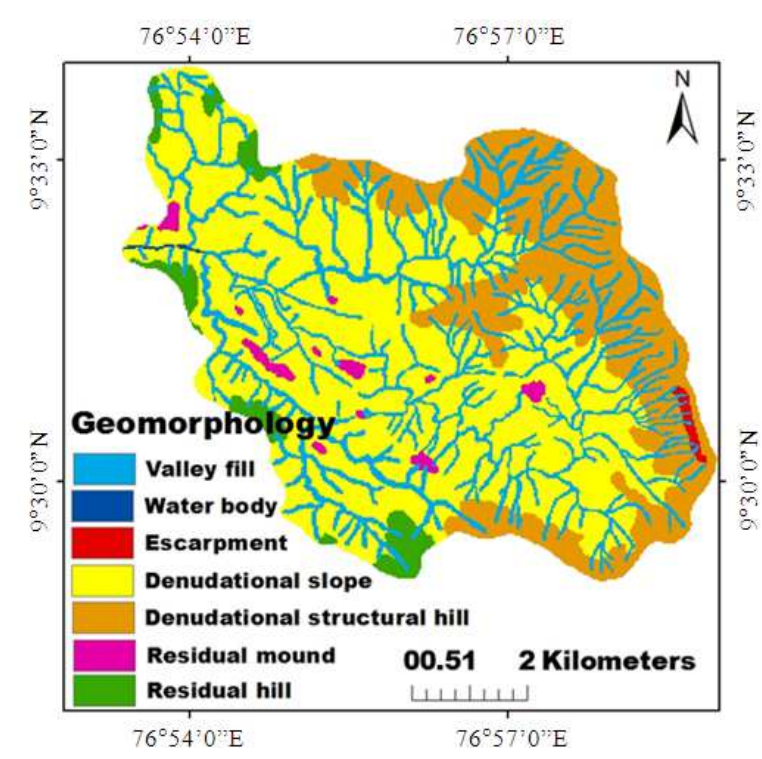

Fig. 3. Geomorphology of Peruvanthanam sub-watershed

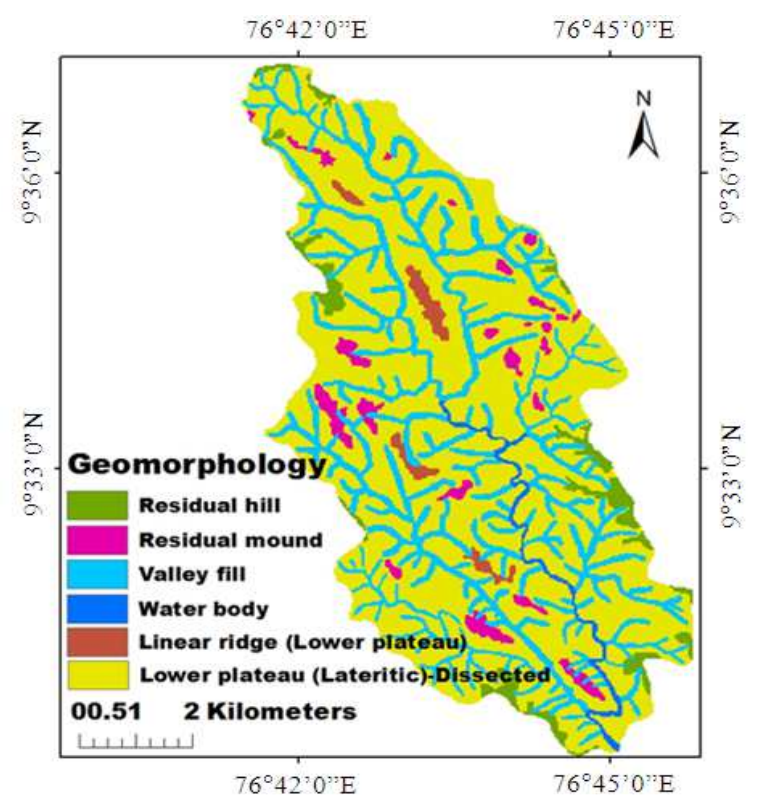

Fig. 4. Geomorphology of Valiyathodu sub-watershed 
Vadakkepurakkal Rekha et al. / American Journal of Environmental Science 9 (1): 62-72, 2013

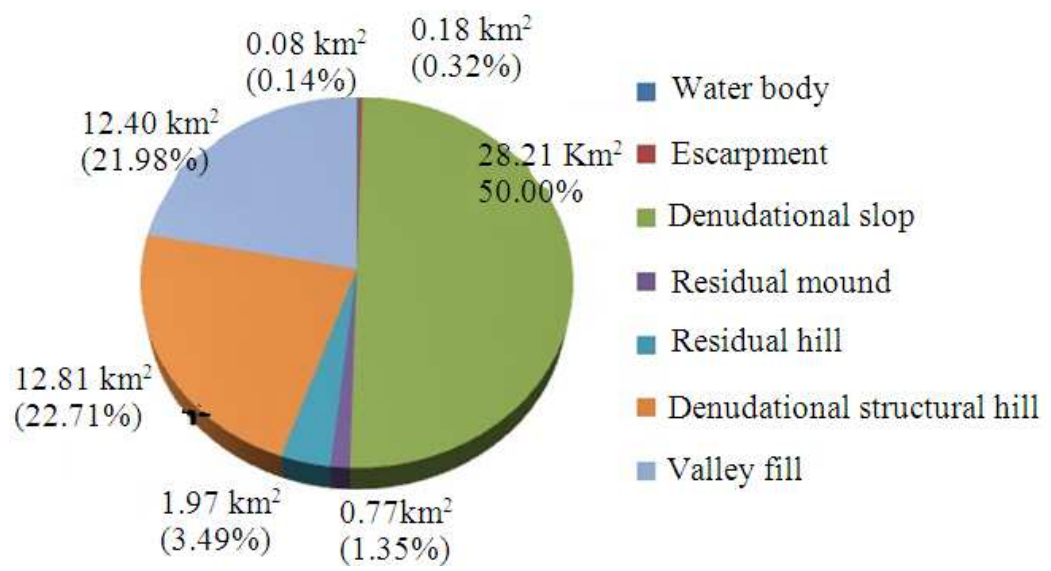

Fig. 5. Distribution of Geomorphology in Peruvanthanam sub-watershed

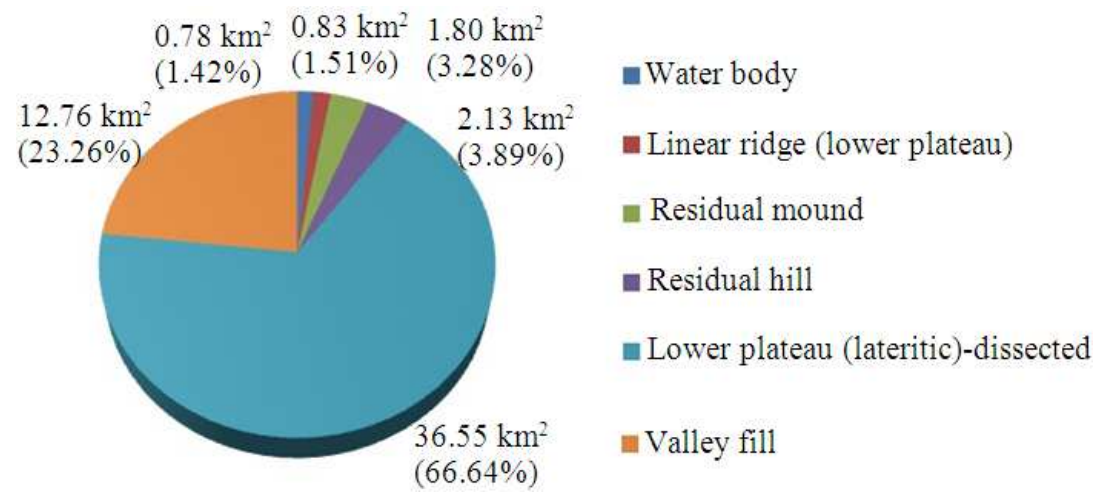

Fig. 6. Distribution of Geomorphology in Valiyathodu sub-watershed

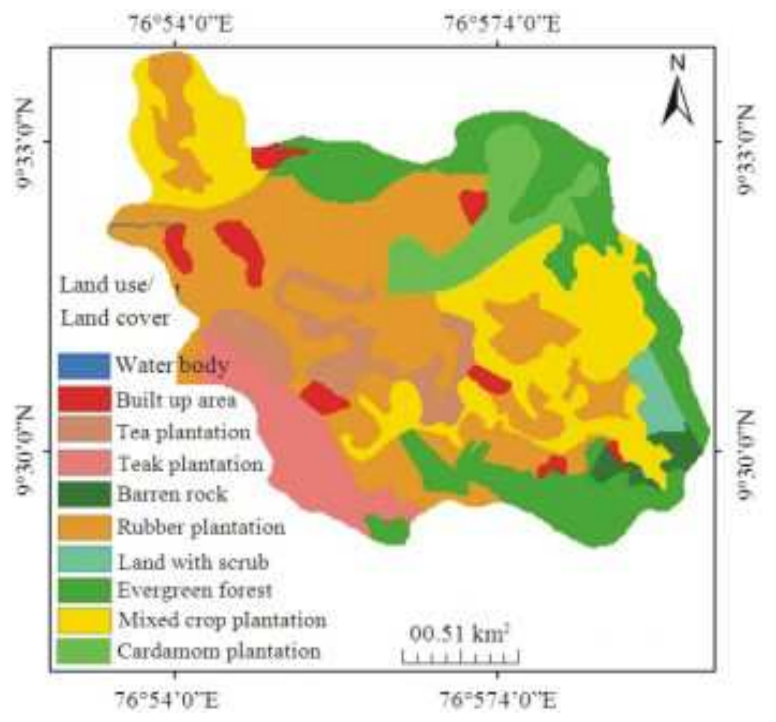

Fig. 7. Land use/Land cover map of Peruvanthanam subwatershed

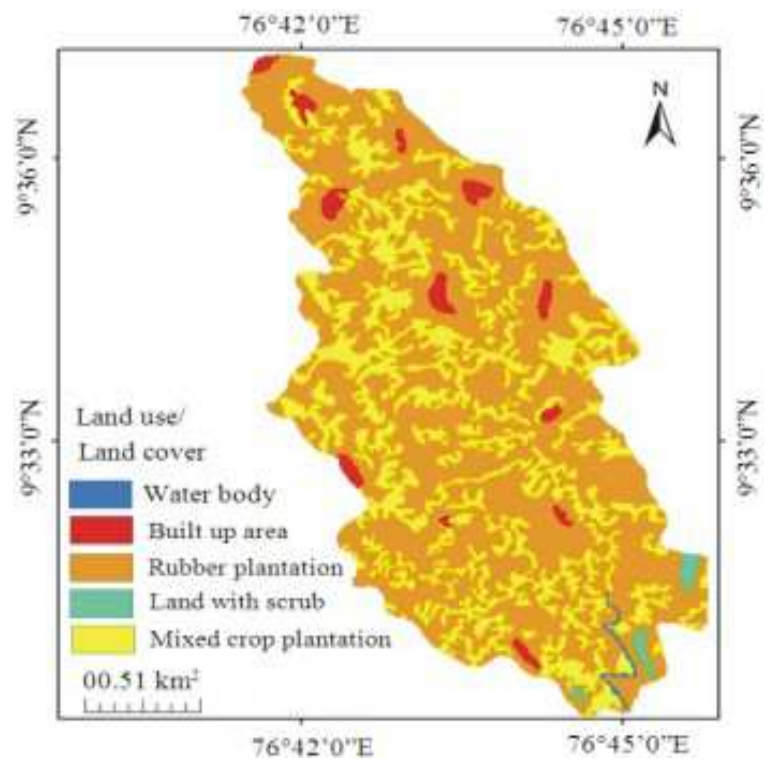

Fig. 8. Land use/Land cover map of Valiyathodu sub-watershed 


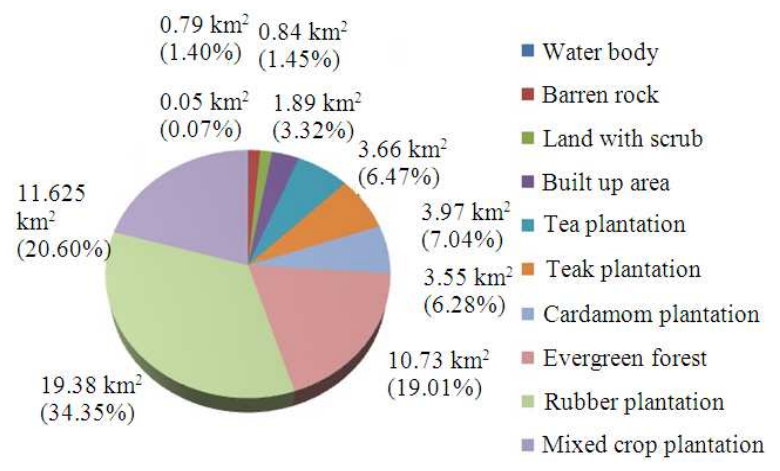

Fig. 9. Distribution of Land use/Land cover in Peruvanthanam sub-watershed

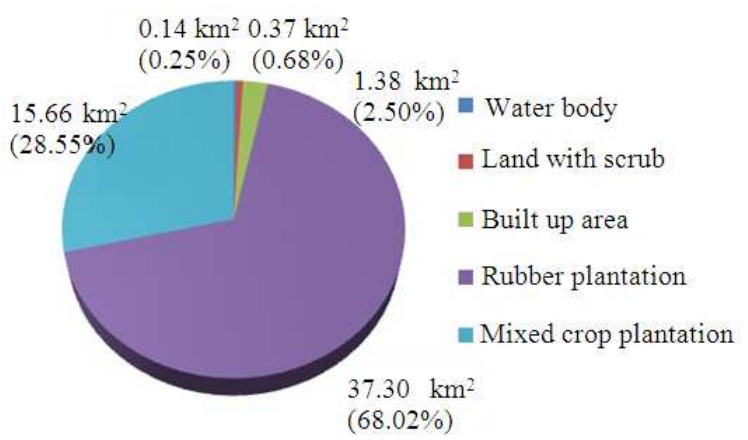

Fig. 10. Distribution of Land use/Land cover in Valiyathodu sub-watershed

DEM is the digital representation of continuous variation of topographic surface that has been carried out by the interpolation of contours, which in turn is digitized from Survey of India toposheets using Arc GIS 9.2. This generated DEM of both Peruvanthanam subwatershed and Valiyathodu sub-watershed (Fig. 11 and 12) is used for generation of slope and 9 classes of DEM delineated in both sub-watersheds.

Based on critical analysis, slope of Peruvanthanam sub-watershed (Fig. 13) is classified in to 5 categories. Majority of the area falls under the class of $5-15^{0}$ $\left(16.46 \mathrm{~km}^{2}\right)$ and minimum under the slope class of $>35$ $\left(3.55 \mathrm{~km}^{2}\right)$. In general, Peruvanthanam sub-watershed has steep slopes which has important role in determining groundwater potentiality. Slope of Valiyathodu subwatershed (Fig. 14) is also classified in to 5 categories. The Major area of Valiyathodu sub-watershed is covered by slope class of $0-4\left(28.96 \mathrm{~km}^{2}\right)$ and minimum area by slope class unit of $>27\left(1.26 \mathrm{~km}^{2}\right)$. The area covered by each slope unit of both sub-watersheds are represented in Fig. 15 and 16.

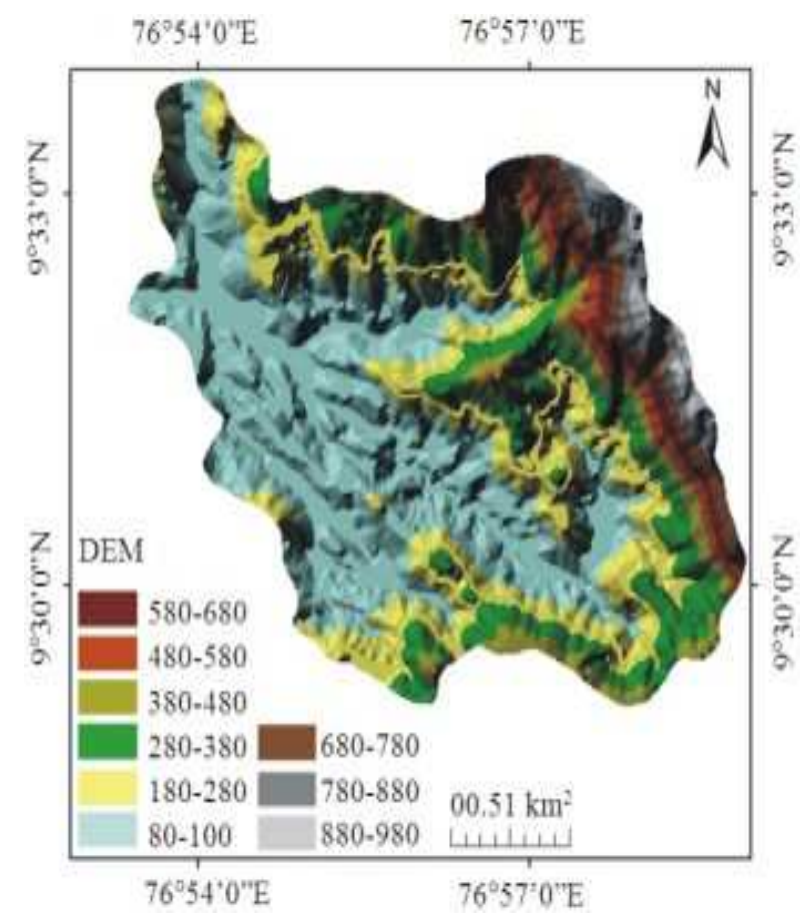

Fig. 11. DEM of Peruvanthanam sub-watershed

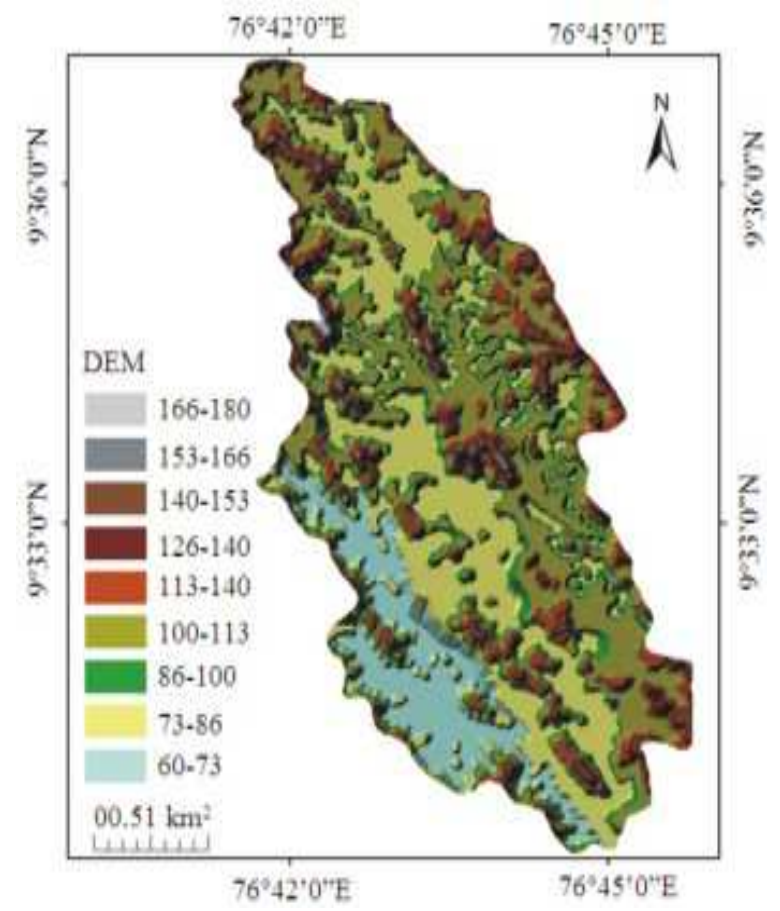

Fig. 12. DEM of Valiyathodu sub-watershed 


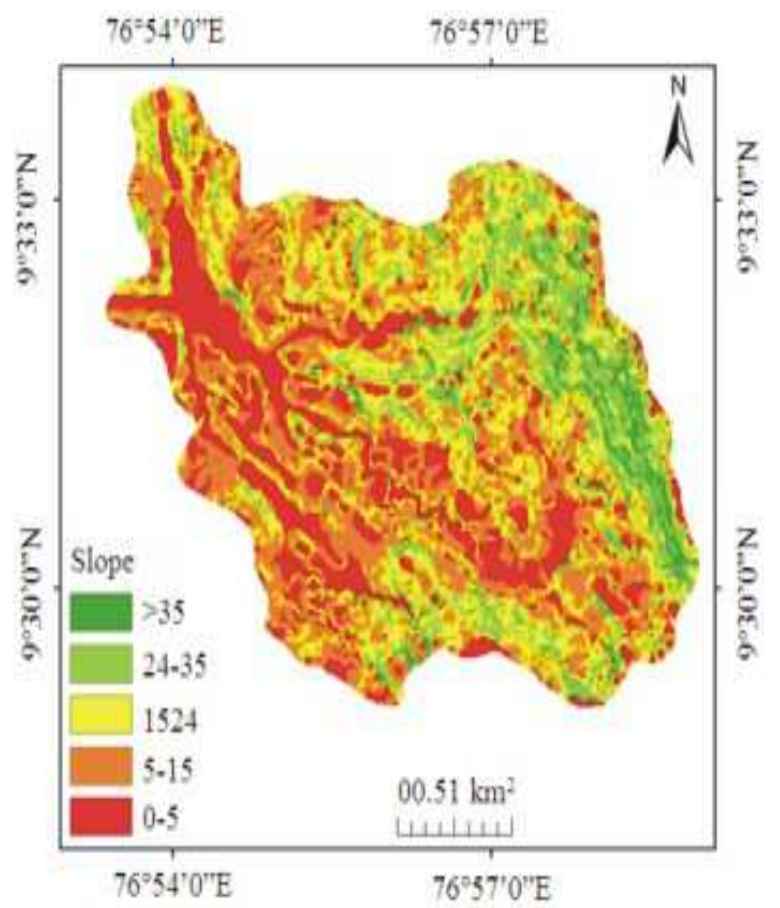

Fig. 13. Slope of Peruvanthanam sub-watershed

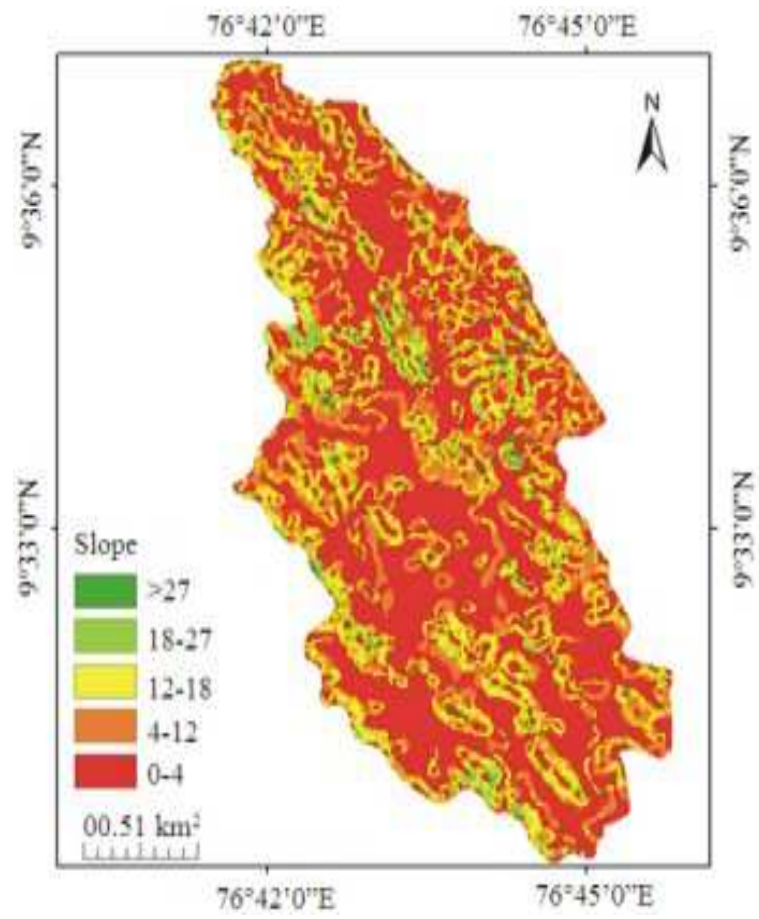

Fig. 14. Slope of Valiyathodu sub-watershed

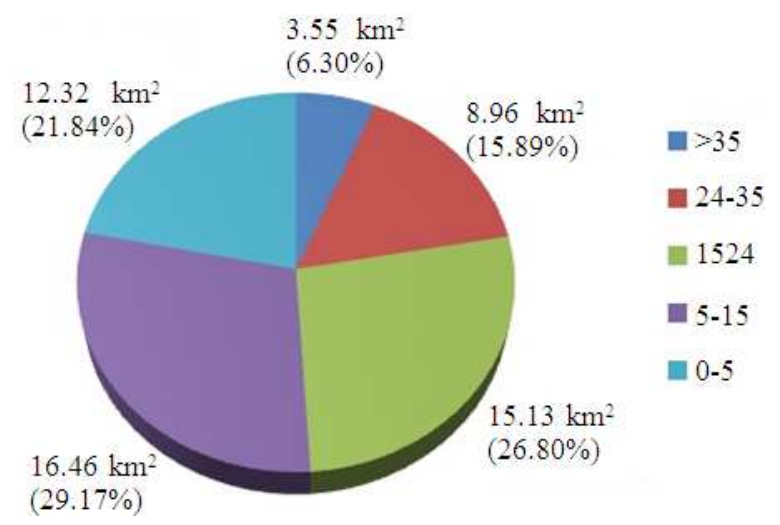

Fig. 15. Distribution of slope in Peruvanthanam sub-watershed

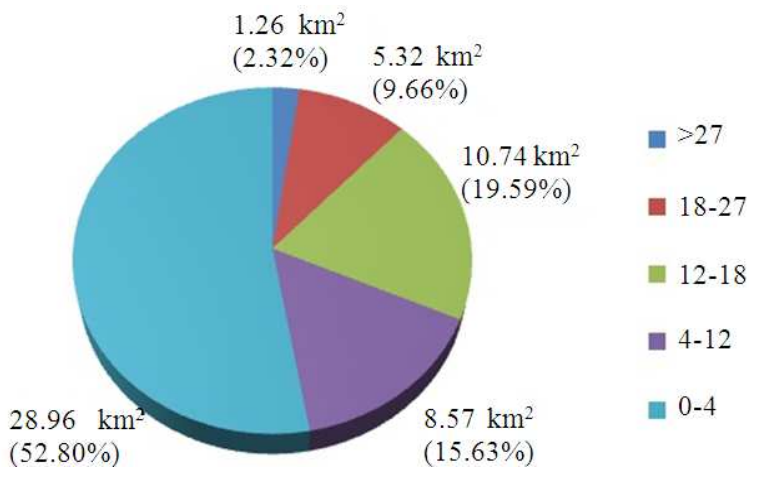

Fig. 16. Distribution of slope in Valiyathodu sub-watershed

\subsection{Geology}

In Peruvanthanam sub-watershed, $87.5 \%$ of the area i.e., $49.39 \mathrm{~km}^{2}$ is covered by precambian formations, mainly charnockite, gneisses and other crystalline rocks followed by intrusive rocks of quartzite and dolerite (Fig. 17). Valiyathodu sub-watershed is also characterized by charnockite and associated crystalline rocks followed by intrusive rocks such as quartzite, dolerite and gabbro (Fig. 18). The area covered by various geological unit in both sub-watersheds are represented in Fig. 19 and 20.

\subsection{Criteria for Assigning Weightage and Rank}

After the preparation of each theme, a specific weightage to each theme and ranks were given to individual features. The influence of different factors need not be same in any area. Therefore each parameter was assigned a weightage depending mainly on its influence on groundwater system. The weightages and scores given for each themes and layer classes of the sub-watersheds are given in Table 2 and 3 respectively. 
Vadakkepurakkal Rekha et al. / American Journal of Environmental Science 9 (1): 62-72, 2013

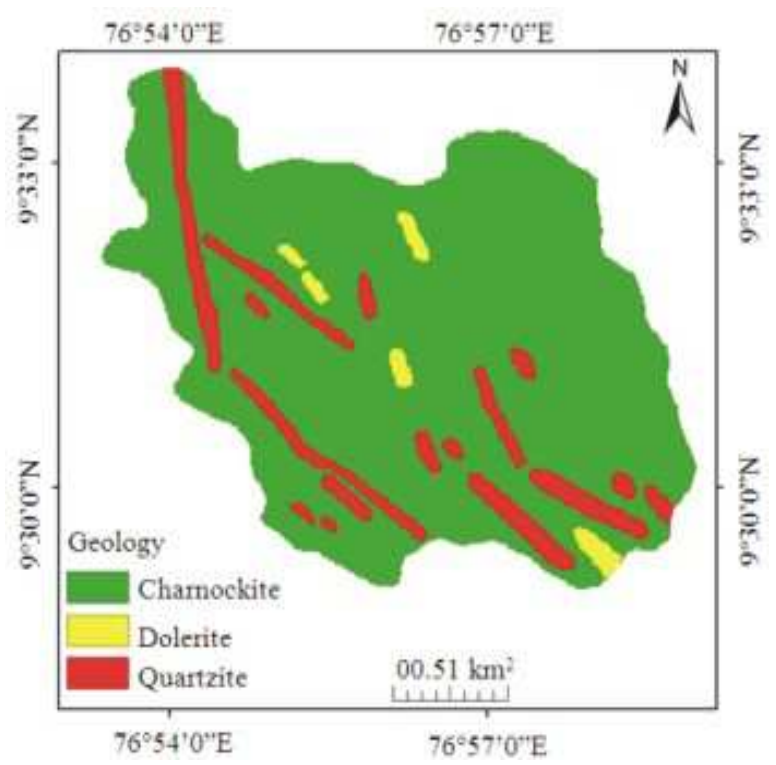

Fig. 17. Geology of Peruvanthanam sub-watershed

Table 2. Weightage and rank given for each theme and individual features of Peruvanthanam sub-watershed

\begin{tabular}{|c|c|c|c|}
\hline $\mathrm{T}$ & layer classes & $\mathrm{W}$ & $\mathrm{R}$ \\
\hline & Water body & & 0 \\
\hline & Escarpment & & 1 \\
\hline & Denudational slope & 40 & 10 \\
\hline & Residual mound & & 13 \\
\hline & Residual hill & & 15 \\
\hline & Denudational & & \\
\hline & Structural hill & & 16 \\
\hline \multirow[t]{5}{*}{ Geomorphology } & Valley fill & & 25 \\
\hline & $>35$ & 30 & 1 \\
\hline & $24-35$ & & 5 \\
\hline & $15-24$ & & 12 \\
\hline & $5-15$ & & 20 \\
\hline \multirow[t]{10}{*}{ Slope } & $0-5$ & & 25 \\
\hline & Water body & 20 & 0 \\
\hline & Barren rock & & 1 \\
\hline & Land with scrub & & 3 \\
\hline & Built up area & & 4 \\
\hline & Tea plantation & & 5 \\
\hline & Teak plantation & & 7 \\
\hline & Cardamom plantation & & 8 \\
\hline & Evergreen forest & & 9 \\
\hline & Rubber plantation & & 10 \\
\hline \multirow[t]{3}{*}{ Land use/Land cover } & Mixed crop plantation & & 21 \\
\hline & Quartzite & 10 & 1 \\
\hline & Dolerite & & 5 \\
\hline Geology & Charnockite & & 18 \\
\hline
\end{tabular}

$\mathrm{T}=$ Theme; $\mathrm{W}=$ Weightage; $\mathrm{R}=$ Rank

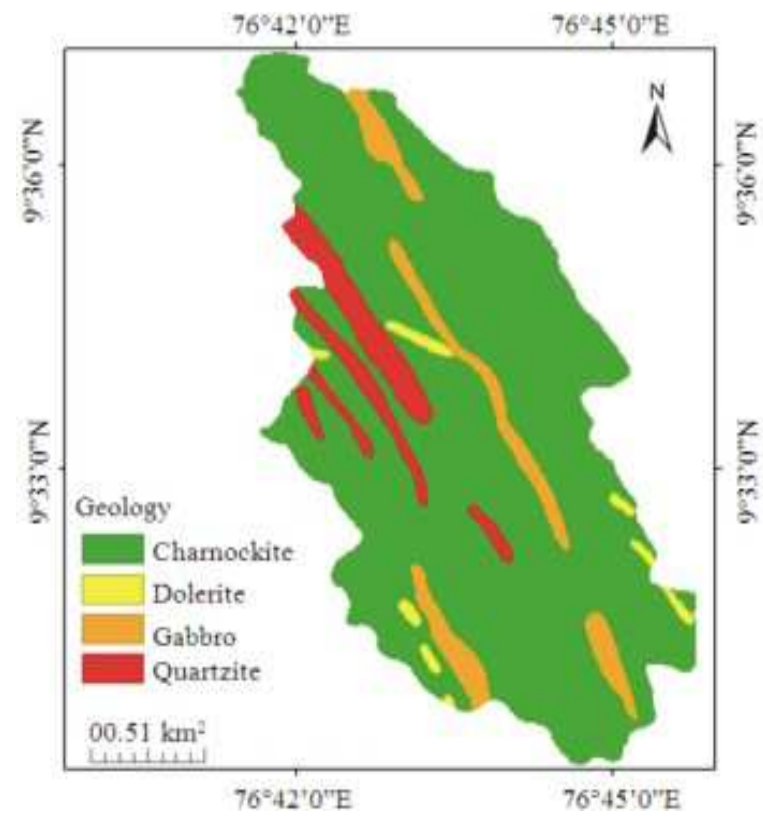

Fig. 18. Geology of Valiyathodu sub-watershed

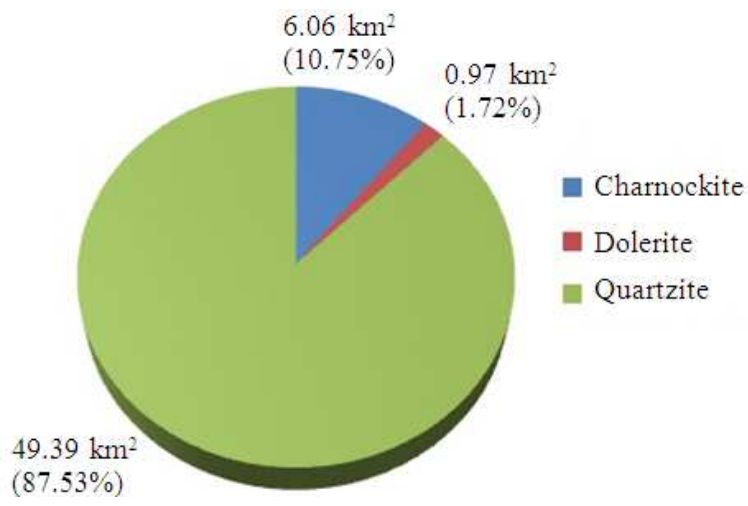

Fig. 19. Distribution of rock type in Peruvanthanam sub-watershed

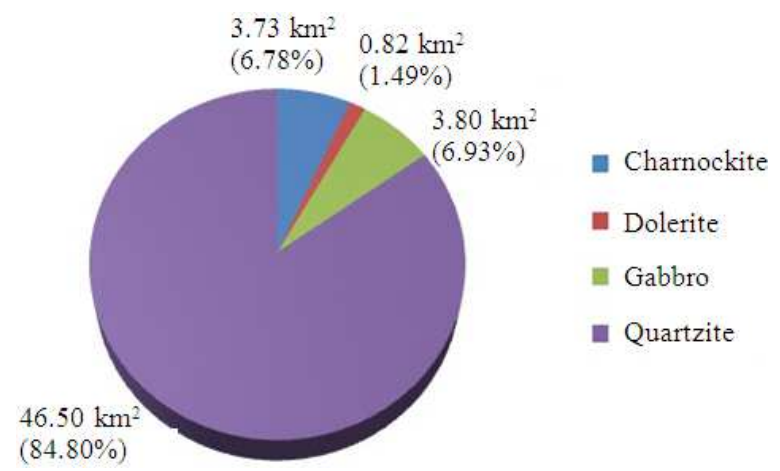

Fig. 20. Distribution of rock type in Valiyathodu sub-watershed 
Table 3. Weightage and rank given for each theme and individual features of Valiyathodu sub-waterhed

\begin{tabular}{|c|c|c|c|}
\hline$T$ & layer classes & $\mathrm{W}$ & $\mathrm{R}$ \\
\hline \multirow{5}{*}{ Slope } & $>27$ & & 2 \\
\hline & $18-27$ & & 6 \\
\hline & $12-18$ & & 13 \\
\hline & $4-12$ & & 18 \\
\hline & $0-4$ & 35 & 24 \\
\hline \multirow[t]{11}{*}{ Geomorphology } & Water body & & 0 \\
\hline & Linear ridge & & \\
\hline & (Lower plateau) & & 5 \\
\hline & Residual mound & & 6 \\
\hline & Residual hill & & 13 \\
\hline & Lower plateau & & \\
\hline & (Lateritic)-dissected & 30 & 16 \\
\hline & Valley fill & & 0 \\
\hline & Water body & & 6 \\
\hline & Land with scrub & & 10 \\
\hline & Built up area & & 14 \\
\hline Land use/ & Rubber plantation & & 19 \\
\hline \multirow{4}{*}{ Land cover } & Mixed crop plantation & 25 & 21 \\
\hline & Quartzite & & 1 \\
\hline & Dolerite & & 5 \\
\hline & Gabbro & & 8 \\
\hline Geology & Charnockite & 10 & 18 \\
\hline
\end{tabular}

$\mathrm{T}=$ Theme; $\mathrm{W}=$ Weightage; $\mathrm{R}=$ Rank

In Peruvanthanam sub-watershed, higher weightage was given to geomorphology followed by slope, land use/land cover and geology, because the influence of geomorphology and slope in Peruvanthanam sub-watershed is comparatively high. In Valiyathodu sub-watershed, higher weightage was given to slope followed Table 3 .

Weightage and rank given for each theme and individual features of Valiyathodu sub-waterhed by geomorphology, land use/land cover and geology. Because the influence of slope in Valiyathodu subwatershed is comparatively high. After assigning weightage, a knowledge based scores ranging from 1 to 25 based on their ability to hold groundwater was given; where 1 denotes poor and 25 denotes excellent prospects.

After assigning the weightages and ranks to the themes and individual features, all the themes were converted to raster format using 'Spatial analyst'-an extention of Arc GIS 9.2 software. While converting to raster, the scores assigned to the individual features were taken as the value field and it is reclassified for the analysis. Then, the individual themes were normalized by dividing theme weightages by 100 . The 'raster calculator' option of spatial analyst was used to prepare the integrated final groundwater potential map of the area. The map algebra used in the raster calculator for both sub-watersheds is as follows.

Thus the Groundwater Potential Map (GPM) of Peruvanthanam sub-watershed $=($ Geomorphology $) \mathrm{X}$
$0.40+$ (Slope) X 0.30+ (Land use/Land cover) X 0.20+ (Geology) X 0.10 and the Groundwater Potential Map $($ GPM $)$ of Valiyathodu sub-watershed $=($ Slope $)$ X $0.35+$ (Geomorphology) X 0.30+ (Land use/Land cover) X $0.25+$ (Geology) X 0.10 .

\section{RESULTS}

The integrated final map was reclassified to generate the output map of both Peruvanthanam (Fig. 21) and Valiyathodu sub-watershed (Fig. 22), showing five classes of groundwater potential zones. These potential zones are designated as 'excellent to very good', 'very good to good' and 'good to moderate', 'moderate to poor' and 'poor to very poor'. The groundwater potential zones and its area in $\mathrm{km}^{2}$ and percentage of Peruvanthanam sub-watershed are represented in Fig. 23 and of Valiyathodu sub-watershed in Fig. 24.

In Peruvanthanam sub-watershed, the 'excellent to very good zone' occupies $7.69 \mathrm{~km}^{2}$ (i.e., $13.64 \%$ ). Where as in Valiyathodu sub-watershed, an area of $26.10 \mathrm{~km}^{2}$ (i.e., $47.58 \%$ ) fall under 'excellent to very good'. In Peruvanthanam sub watershed 'very good to good' potential which covers an area of $14.87 \mathrm{~km}^{2}$ (i.e., $26.35 \%)$. On the other hand, in Valiyathodu sub watershed, an area of $18.55 \mathrm{~km}^{2}$ (i.e., $33.82 \%$ ) belongs to this category. In Peruvanthanam sub-watershed, a zone of 'good to moderate' potential which is represented by 17.65 $\mathrm{km}^{2}$ (i.e., $31.28 \%$ ). In Valiyathodu sub-watershed, 'good to moderate' zone, is occupied by $6.65 \mathrm{~km}^{2}$ (i.e., $12.12 \%$ ).

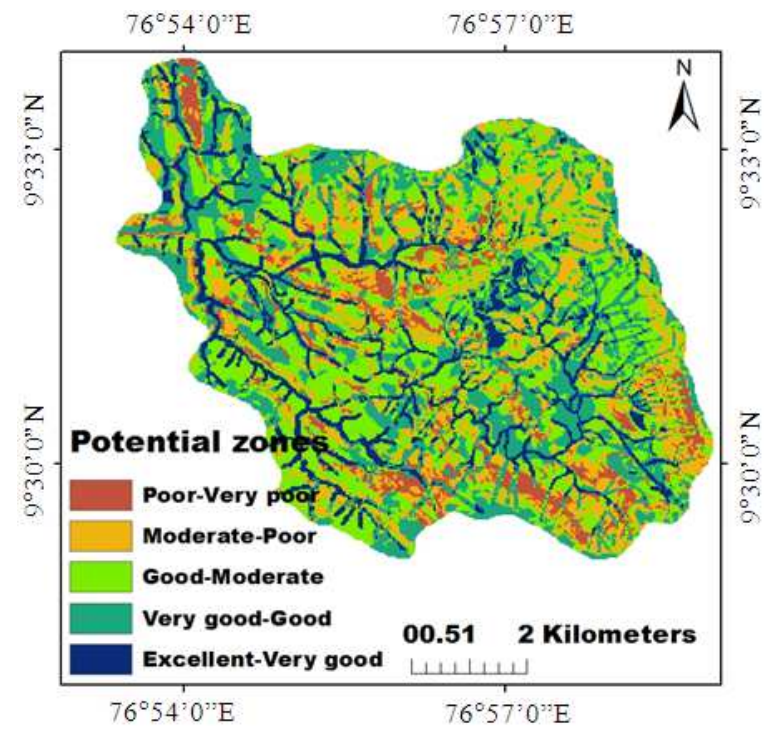

Fig. 21. Groundwater potential zones of Peruvanthanam sub-watershed 


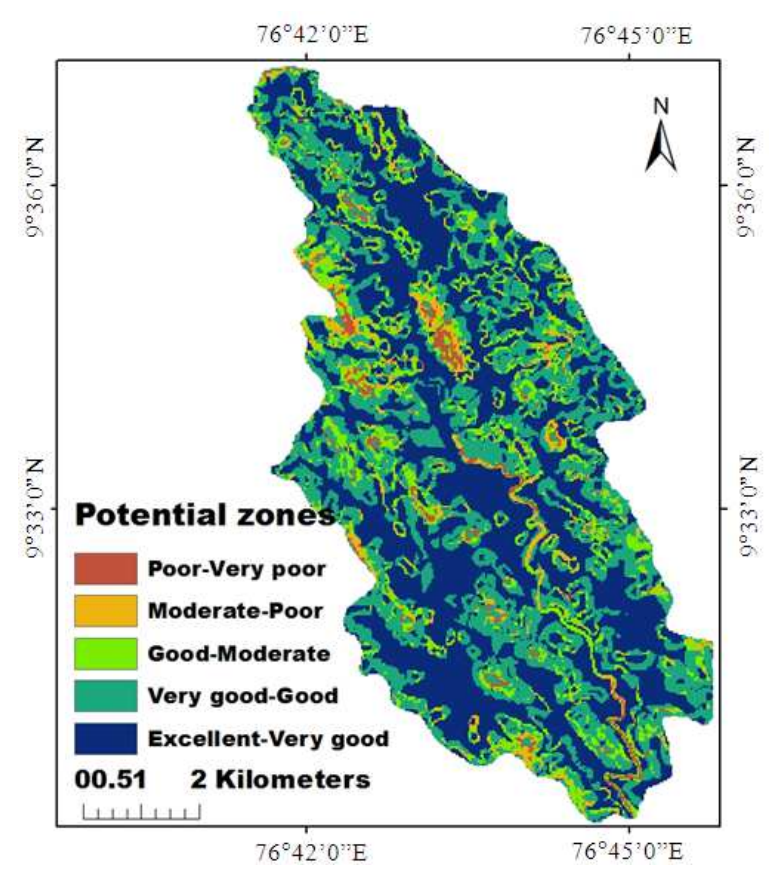

Fig. 22. Groundwater potential zones of Valiyathodu subwatershed

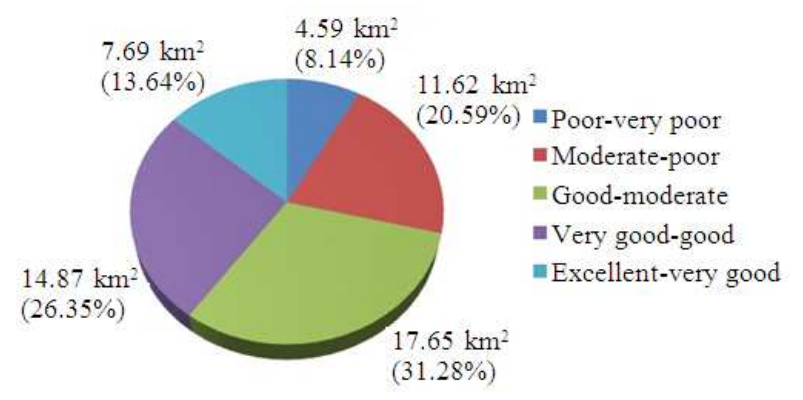

Fig. 23. Distribution of potential zones in Peruvanthanam sub-watershed

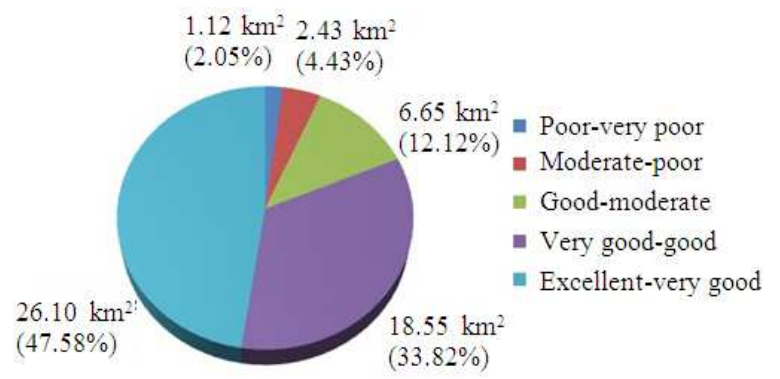

Fig. 24. Distribution of potential zones in Valiyathodu subwatershed
In Peruvanthanm sub-watershed, the zone 'moderate to poor' which covers an area of $11.62 \mathrm{~km}^{2}$ (i.e., 20.59 $\%$ ), whereas in Valiyathodu sub-watershed, the area covered by this zone is $2.43 \mathrm{~km}^{2}$ (i.e., $4.43 \%$ ). In Peruvanthanm sub-watershed, 'poor to very poor' zone covered by this zone is $4.59 \mathrm{~km}^{2}$ (i.e., $8.14 \%$ ) whereas in Valiyathodu sub-watershed, the area covered by this zone is $1.12 \mathrm{~km}^{2}$ (i.e., $2.05 \%$ ).

\section{DISCUSSION}

In Peruvanthanam sub-watershed, in 'excellent to very good zone', the slope belongs to $0-5^{0}$ class. This restricts the surface run off and accelerates infiltration. Along with this, geomorphologic units such as valley fills of ever green forest, mixed crop plantation, favours excellent recharge condition, whereas in Valiyathodu sub-watershed, the presence of valley fill, lower plateau of geomorpholologic unit, slope of $0-4^{0}$ and mixed crop plantation land use/land cover unit, makes the zone excellent to very good. In Peruvanthanam subwatershed, slope class of $5-15^{\circ}$ and land use/land cover unit of rubber plantation, cardamom plantation and teak plantation makes this a zone of 'very good to good'. In such a situation, both dug wells and bore wells are suggested. In Valiyathodu sub-watershed, the slope unit of $4-12^{0}$, land use/land cover unit with rubber plantation geomorphologic units of residual hills make this zone 'very good to good' potential. In Peruvanthanam subwatershed slope of $\left(15-24^{0}\right)$ and land use/land cover units of built up area, geomorphological units of denudational structural hills decelerate the infiltration and make this a zone of 'good to moderate' potential. In sub-watershed, the infiltration is decelerated by, the factors such as, slope of $12-18^{\circ}$, land use/land cover unit such as land with scrub geomorphologic unit of residual hill and these factors make this a zone of 'good to moderate' potential. In Peruvanthanm sub-watershed,slope class of $24-35^{\circ}$ characterized by geomorphological units such as residual mound, escarpment, built up area of land use/land cover units, geological units with charnockite rocks together make the zone 'moderate to poor'. In Valiyathodu sub-watershed, slope class of $18-27^{0}$, geomorphological units such as residual mound, built up area of land use/land cover units and geology with charnockite rocks make the zone 'moderate to poor'. In Peruvanthanam sub-watershed, the 'poor to very poor' potential zone, is represented mostly by rocky terrain with charnockite as predominant rock type. Here the slope condition $\left(>35^{0}\right)$ and land use condition that mainly covers with built up area, makes a run off zone 
with 'poor to very poor' groundwater prospects. In Valiyathodu sub-watershed also, poor to very poor zone is marked by rocky terrain with geomorphology as residual mount and land use/land cover unit as built up area. Slope is $>27^{0}$. In these areas groundwater potentiality is very limited. Active rain water harvesting has to be initiated here in both sub-watersheds to face the water scarcity problems.

\section{CONCLUSION}

The study based on the utility of remote sensing and raster based GIS technique is focused on the identification and delineation of groundwater potential zones. Multi Criteria Evaluation Technique (MCE) by integration of various thematic maps prepared from conventional and remote sensing techniques using GIS yields more and near accurate result. Based on this the entire study area has been classified in to five potential zones. Critical analysis and comparison of ground water potential zones of both sub-watersheds revealed various potential zones and area represented by each zones. Further the study shows that in general a groundwater potential zone is more in Valiyathodu sub-watershed compared to Peruvanthanam. The groundwater potential map derived from the present study will provide a baseline data for any future exploration in these areas. Finally, it is suggested that, proper rainwater harvesting and artificial recharge methods and measures should be implemented in 'moderate to very poor' and 'poor to very poor' potential areas for overcoming the water scarcity problem and for future development of water use strategies.

\section{ACKNOWLEDGEMENT}

The Searchers gratefully acknowledge the Director, School of Environmental Science, MG University, Kottayam and Head of the Department of Central University of Kerala, Kasargode, for the support extended and facilities provided during the course of study.

\section{REFERENCES}

Das, D., S.C. Behara, A. Kar, P. Narendra and S. Guha, 1997. Hydrogeomorphological mapping in ground water exploration using remotely sensed data-a case study in Keonjhar district, Orissa. J. Ind. Soc. Remo. Sens., 25: 247-259. DOI: 10.1007/BF03019366
Devi, S.P., S. Srinivasalu and K.K. Raju, 2001. Hydrogeomorphological and groundwater prospects of the Pageru river basin by using remote sensing data. Environ. Geol., 40: 1088-1094. DOI: 10.1007/s002540100295

Gopinath, G. and P. Saralathan, 2004. Identification of groundwater prospective zones using IRS-ID liss iii and pump test methods. J. Ind. Soc. Remo. Sens., 32: 329-342. DOI: 10.1007/BF03030858

Khan, M.A. and P.C. Moharana, 2002. Use of remote Sensing and geographical information system in the delineation and characterization of ground water prospect zones. J. Ind. Soc. Remo. Sens., 30: 131-141. DOI: 10.1007/BF02990645

Krishnamurthy, J. and G. Srinivas, 1995. Role of geological and geomorphological factors in ground water exploration: A study using IRS LISS data. Int. J. Remo. Sens., 16: 2595-2618. DOI: 10.1080/01431169508954579

Mayilvaganan, M.K., P. Mohana and K.B. Naidu, 2011. Delineating groundwater potential zones in Thurinjapuram watershed using geospatial techniques. Ind. J. Sci. Technol., 4: 1470-1476.

Prasad, R., N. Dinesh, A. Lee, E. Miltsakaki and L. Robaldo et al., 2008. The Penn Discourse TreeBank 2.0. Proceedings of the Sixth International Conference on Language Resources and Evaluation, May 28-30, European Language Resources Association.

Rao, Y.S., T. Reddy and P. Nayudu, 2000. Groundwater targeting in a hard-rock terrain using fracturepattern modeling, Niva river basin andhra Pradesh, India. J. Hydrogeol., 8: 494-502. DOI: 10.1007/s100400000090

Ravindran, K.V. and A. Jeyaram, 1997. Groundwater prospects of Shahbad Tehsil, Baran District, Eastern Rajasthan: A remote sensing approach. J. Ind. Soc. Remote Sens., 25: 239-246.DOi: DOI: 10.1007/BF03019365

Ravishankar, M.N. and G. Mohan, 2006. Assessment of the groundwater potential and quality in Bhatsa and Kalu river basins of Thane district, western Deccan Volcanic Province of India. Environ. Geol., 49: 991-998. DOI: $10.1007 / \mathrm{s} 00254-005-0137-5$ 
Saraf, A.K. and P.R. Choudhary, 1998. Integrated remote sensing and GIS for groundwater exploration and identification of artificial recharge sites. Int. J. Remote Sens., 19: 1825-1841. DOI: 10.1080/014311698215018

Sarkar, B.C., B.S. Deota, P.L.N. Raju and D.K. Jugran, 2001. A Geographic Information System approach to evaluation of groundwater potentiality of Shamri micro-watershed in the Shimla Taluk, Himachal Pradesh. J. Ind. Soc. Remote Sens., 29: 151-164. DOI: $10.1007 / \mathrm{BF} 02989927$
Srivasthava, P.K. and A.K. Bhattacharya, 2000 Delineation of ground water potential zones in a hard rock terrain of bargarh district, orissa using IRS data. J. Ind. Soc. Remote Sens., 28: 129-140. DOI: $10.1007 / \mathrm{BF} 02989897$

Taylor, R. and K. Howard, 2000. A tectono-geomorphic model of the hydrogeology of deeply weathered crystalline rock: Evidence from Uganda. Hydrogeol. J., 8: 279-294. DOI: 10.1007/s 100400000069 